\title{
Getz Ice Shelf melt enhanced by freshwater discharge from beneath the West Antarctic Ice Sheet
}

\author{
Wei Wei ${ }^{1}$, Donald D. Blankenship ${ }^{1}$, Jamin S. Greenbaum ${ }^{1}$, Noel Gourmelen ${ }^{2}$, Christine F. Dow ${ }^{3}$, Thomas G. Richter ${ }^{1}$, \\ Chad A. Greene ${ }^{4}$, Duncan A. Young ${ }^{1}$, SangHoon Lee ${ }^{5}$, Tae-Wan Kim ${ }^{5}$, Won Sang Lee ${ }^{5}$, and Karen M. Assmann ${ }^{6, a}$ \\ ${ }^{1}$ Institute for Geophysics and Department of Geological Sciences, Jackson School of Geosciences, \\ University of Texas at Austin, Austin, Texas, USA \\ ${ }^{2}$ School of GeoSciences, University of Edinburgh, Edinburgh, UK \\ ${ }^{3}$ Department of Geography and Environmental Management, University of Waterloo, Waterloo, Ontario, Canada \\ ${ }^{4}$ Jet Propulsion Laboratory, California Institute of Technology, Pasadena, California, USA \\ ${ }^{5}$ Korea Polar Research Institute, Incheon, South Korea \\ ${ }^{6}$ Department of Earth Sciences, University of Gothenburg, Gothenburg, Sweden \\ a present address: Institute of Marine Research, Troms $\varnothing$, Norway
}

Correspondence: Wei Wei (wwei@utexas.edu)

Received: 18 July 2019 - Discussion started: 26 July 2019

Revised: 8 March 2020 - Accepted: 10 March 2020 - Published: 27 April 2020

\begin{abstract}
Antarctica's Getz Ice Shelf has been rapidly thinning in recent years, producing more meltwater than any other ice shelf in the world. The influx of fresh water is known to substantially influence ocean circulation and biological productivity, but relatively little is known about the factors controlling basal melt rate or how basal melt is spatially distributed beneath the ice shelf. Also unknown is the relative importance of subglacial discharge from the grounded ice sheet in contributing to the export of fresh water from the ice shelf cavity. Here we compare the observed spatial distribution of basal melt rate to a new sub-iceshelf bathymetry map inferred from airborne gravity surveys and to locations of subglacial discharge from the grounded ice sheet. We find that melt rates are high where bathymetric troughs provide a pathway for warm Circumpolar Deep Water to enter the ice shelf cavity and that melting is enhanced where subglacial discharge fresh water flows across the grounding line. This is the first study to address the relative importance of meltwater production of the Getz Ice Shelf from both ocean and subglacial sources.
\end{abstract}

\section{Introduction}

The Getz Ice Shelf (Getz herein) in West Antarctica is over $500 \mathrm{~km}$ long and 30 to $100 \mathrm{~km}$ wide; it produces more fresh water than any other source in Antarctica (Rignot et al., 2013; Jacobs et al., 2013), and in recent years its melt rate has been accelerating (Paolo et al., 2015). The fresh, buoyant water that emanates from the Getz cavity drives regional and global ocean circulation (Nakayama et al., 2014; Jourdain et al., 2017; Silvano et al., 2018) while providing critical nutrients for biological production (Raiswell et al., 2006), but little is known about the origins or sensitivities of this major freshwater source. Specifically, the variability in fresh water from ice shelf melt has not been modeled due to poorly constrained bathymetry beneath the ice shelf, which has resulted in a poor understanding of how water circulates throughout the ice shelf cavity. And to date, despite the major role that fresh water from Getz plays in the Southern Ocean, no studies have considered the contribution of subglacial meltwater that originates beneath grounded ice or its role in influencing the circulation and melt patterns beneath the ice shelf.

To understand the potential pathways for warm ocean water to enter into the Getz cavity, we conducted a bathymetric survey using a ship-based, gravimeter-equipped helicopter. As part of a collaboration between the University of Texas Institute for Geophysics (UTIG) and Korea Polar Research 
Institute (KOPRI), an AS350 helicopter was outfitted with an aerogeophysical instrument suite adapted from a design which has previously been operated from fixed-wing aircraft (Greenbaum et al., 2015; Tinto and Bell, 2011). Operating from the RV icebreaker Araon off the Getz coast (see Supplement, Fig. S1), the survey covered areas between Dean Island and Siple Island located in the west of Getz (green lines in Fig. 1) and crossed existing coast-parallel Operation IceBridge (OIB) lines (blue lines in Fig. 1). Gravimetry from the helicopter platform can achieve a higher resolution than conventional fixed-wing surveys, $3 \mathrm{~km}$ and $4.9 \mathrm{~km}$, respectively, due to the lower flying speed of the helicopter. This is the first ever demonstration of the technical and logistical feasibility of gravity observations from a helicopter operating from a ship at sea to obtain high-resolution gravity data over an Antarctic ice shelf.

We used the airborne gravity data to infer the bathymetry beneath Getz (see Sect. 2.2, "Bathymetry inversion approach"). We also developed a new high-resolution map of Getz basal melt rates using satellite radar altimetry data from the years 2010 to 2016 (see Sect. 2.4, "Observed basal melt rate") to understand where ice shelf melt may be correlated with underlying bathymetry. By comparing locations and rates of melt with our new understanding of the Getz cavity bathymetry, we gain first insights into where ice shelf melt is dominated by contact with Circumpolar Deep Water (CDW) and where bathymetry blocks the flow of CDW. We also considered the potential role of subglacial discharge as a mechanism that can cause locally enhanced melt rates (Le Brocq et al., 2013; Marsh et al., 2016). We used the Glacier Drainage System (GlaDS) model, which simulates the coevolution of subglacial distributed and channelized drainage networks that have been demonstrated to correspond well with geophysical data of basal water systems (Dow et al., 2020). We applied this model to estimate the production rate and spatial distribution of subglacial meltwater (Werder et al., 2013; Dow et al., 2016, 2018; see Sect. 2.3, "Subglacial hydrological model"). We then compared the spatial distribution of observed ice shelf melt to locations and flux rates from subglacial discharge locations predicted by GlaDS.

\section{Methods}

We present three types of data in the study: the spatial distribution of basal melt rate (see Figs. 2b and 3), bathymetry inferred from airborne gravity surveys (shown in Fig. 2a), and locations of subglacial discharge (see Fig. 3) from the grounded ice sheet. We inferred the bathymetry of Getz using profile gravity inversions with the Geosoft GM-SYS software. The subglacial hydrological analysis was generated by the two-dimensional GlaDS model (Werder et al., 2013). The observed basal melt rates were computed using a mass conservation approach from Jenkins (1991) and Gourmelen et al.

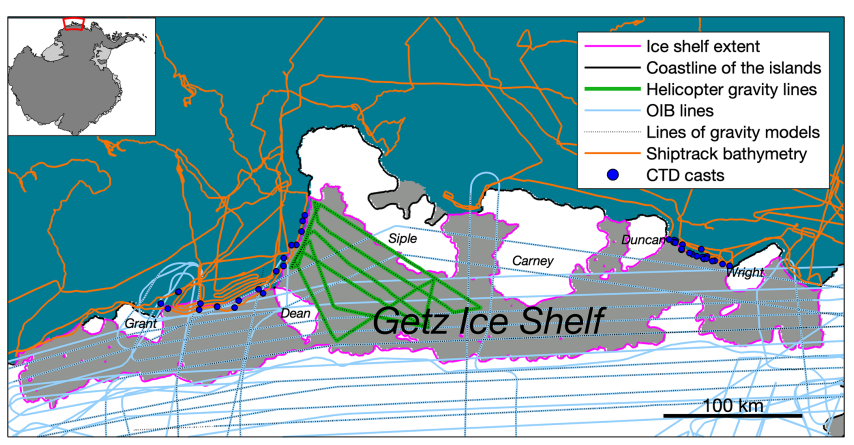

Figure 1. The geographic location and data coverage of Getz. The blue area is ocean. The gray area is Getz Ice Shelf. The white area is grounded ice. Colored lines and marks denote the ice shelf extent (Mouginot et al., 2017), helicopter gravity data, NASA OIB data (Cochran and Bell, 2010a), ship track bathymetry (Nitsche et al., 2007) and CTD casts (Locarnini et al., 2013). This plot is generated from the Antarctic Mapping Tool (Greene et al., 2017).

(2017b) and corrected for melting driven by warm ocean waters using ice bottom elevation and nearby ocean temperature profiles (Holland et al., 2008).

\subsection{Helicopter gravity data acquisition}

The gravity data used in this paper were acquired aboard two aircraft types, one fixed-wing aircraft and one helicopter. Figure 1 shows the data coverage. The OIB data (Cochran and Bell, 2010a) were acquired using the Sander Geophysics Limited (SGL) AIRGrav system aboard NASA's DC-8. More details on this airborne geophysical platform can be found in the literature (Cochran and Bell, 2012; Cochran et al., 2014). The helicopter-based data were acquired using a Canadian Micro Gravity GT-1A in a collaboration between UTIG and KOPRI. Figure S1 shows the helicopter gravity data acquisition platform on the icebreaker Araon. Three dedicated aerogeophysical flights were accomplished in $1 \mathrm{~d}$ of helicopter operations from the Araon while off the coast of western Getz, acquiring about 1200 line-kilometers of data. The gravity anomaly (Fig. S2) suggests the effectiveness of combining OIB and helicopter data. The observed gravity anomaly ranges from -60 to $30 \mathrm{mGal}$ (Fig. S2). The high anomaly strongly correlates with the ice rises and grounded icebergs. Large positive gravity anomalies of up to $30 \mathrm{mGal}$ are consistently found over Grant Island, Dean Island, Siple Island, and Wright Island. The areas between ice rises correspond to low gravity anomalies.

Both survey data sets show similar repeatability statistics with $\sim 1.4$ to $1.6 \mathrm{mGal}$ root mean square (RMS) in the differences at crossovers between lines both internally in each set and between sets. The ship-based UTIG-KOPRI gravity set did not have an absolute gravity tie so that entire survey set was level shifted to minimize the difference in the mean 
of crossovers with the OIB data; no other adjustments were made.

\subsection{Bathymetry inversion approach}

The gravity data are inverted for depth of targets using GMSYS Profile Modelling, a 2D gravity modeling and inversion module in Geosoft. In the forward-modeling mode, the module computes the gravity response from a polygonapproximated irregular target model (Talwani et al., 1959). In the inversion mode, the polygon-approximated model is adjusted iteratively to fit the observed gravity data best. Getz is pinned on an array of islands and peninsulas, so our bathymetry inversion is well constrained by the location of the ice rises and the peninsulas. The bathymetry model is updated iteratively until the difference between modeled gravity and observed gravity values is minimized (convergence limit $=0.1 \mathrm{mGal} ; 0.1 \mathrm{mGal}$ is the standard error of observed gravity data). To better condition the inversion process, we fix the top and bottom of the ice layers, whose depths and topography are obtained from radar data. Similar approaches to infer bathymetry from airborne gravity data have been applied in many regions of Antarctica (Tinto and Bell, 2011; Cochran and Bell, 2012; Muto et al., 2016; Millan et al., 2017; Greenbaum et al., 2015).

We first use the gravity data from grounded ice lines to invert for bedrock densities. For those areas covered by the grounded ice lines, we assume a three-layer model: a solid ice layer with density of $917 \mathrm{~kg} \mathrm{~m}^{-3}$ of known thickness over a bedrock layer, whose density is our free parameter; the third layer is the upper mantle with a density of $3300 \mathrm{~kg} \mathrm{~m}^{-3}$ at a depth of $20 \mathrm{~km}$. The top, bottom, and thickness of the ice layer is obtained from OIB measurement and thus fixed throughout the inversion. We start the inversion with an initial guess of granitic rock density value $2.75 \mathrm{~kg} \mathrm{~m}^{-3}$ since west of the survey area has granite outcrop (Mukasa and Dalziel, 2000).

The gravity data from floating ice lines are used to invert for the bathymetry under Getz. We use a four-layer model: the first layer is an ice layer with density of $0.917 \mathrm{~kg} \mathrm{~m}^{-3}$ with a known depth; the second layer is a seawater layer with a density of $1030 \mathrm{~kg} \mathrm{~m}^{-3}$ - the depth of this layer is our free parameter; the third layer is a bedrock layer with density inferred from grounded-ice-line gravity data; the fourth layer is the upper mantle with a density of $3300 \mathrm{~kg} \mathrm{~m}^{-3}$ at a depth of $20 \mathrm{~km}$. The lines are processed one by one starting from those that are closer to grounded ice lines. The bathymetry model is updated iteratively until the difference between modeled gravity and observed gravity values is minimized (convergence limit $=0.1 \mathrm{mGal} ; 0.1 \mathrm{mGal}$ is the standard error of observed gravity data). The polygon densities applied in this region are in Fig. S3. The constructed 2D models can be found in Fig. S4.

The different $2 \mathrm{D}$ bathymetric profiles are merged through the minimum curvature gridding method, provided by the
Grid and Image module from Geosoft Oasis montaj. The details of the minimum curvature method can be found in Briggs (1974). The mesh size of the interpolated grid is $1792 \mathrm{~m}$. To prevent aliasing and high-frequency signals, we increase the low-pass desampling factor (i.e., the number of grid cells that are averaged). This factor (set to 3) removes high-frequency signals since it acts as a low-pass filter by averaging all points in the nearest cell. The distance between grid cells and a valid point greater than the blanking distance (set to $2000 \mathrm{~m}$ ) are blanked out in the final grid. However, gridding could still introduce artifacts at the intersection points. We calculate the offsets at the profile intersections, and the average offset is about $20 \mathrm{~m}$. The final derived bathymetry (Fig. 2a) includes the Getz Ice Shelf bathymetry from gravity inversion and offshore bathymetry from IBCSO (International Bathymetric Chart of the Southern Ocean; Arndt et al., 2013).

We follow the uncertainty estimation approach from Greenbaum et al. (2015). We compare the inversion with the geometry of the grounded ice as a measure of the uncertainty beneath the floating ice assuming that the bed roughness under grounded ice and floating ice is similar. Our estimated root-mean-square error (RMSE) between the ice bottom measured by radar and sampled from the bathymetry model is about $246 \mathrm{~m}$, and the mean offset between the two is about $44 \mathrm{~m}$ (see Fig. S5). We also compare the overlapping points where the gravity lines intersect with the ship track (Nitsche et al., 2007). The RMSE between the ship-measured bathymetry and that sampled from the bathymetry model is about $121 \mathrm{~m}$; the mean offset between the two is about $32 \mathrm{~m}$ (see Fig. S5).

We do not include significant geological or sedimentary signatures in our model since we have insufficient magnetic analysis over Getz. But our methods do account for local geological heterogeneity (see Fig. S3). Published interpretations within the ASE (Amundsen Sea Embayment) imply that we should not expect a significant crustal thickness gradient or sedimentary basin beneath the Getz Ice Shelf (Gohl et al., 2013). Therefore, we expect sediments near the grounding line to be scoured away as seen in other ice shelves of ASE (Gohl et al., 2013; Cochran et al., 2014). However, if the sediment is present, it will cause the gravity-derived bathymetry to be deeper than the actual seafloor. If we are correct and no significant geological structure underlies Getz, then the existence of sediments will shift the bathymetry to be deeper but will not change the shape of the bathymetry and thus will not affect our conclusions.

\subsection{Subglacial hydrological model}

The subglacial hydrological analysis is generated by the twodimensional GlaDS model (Werder et al., 2013). Distributed flow occurs through linked cavities that are represented as a continuous water sheet of variable thickness. Channels grow along finite element edges and exchange water with 
the adjacent distributed system, as part of a fully coupled 2D drainage network. The model is run at the steady state over $3000 \mathrm{~d}$ with primary outputs being channel discharge over the domain and the grounding line into the Getz cavity. Topography inputs are from airborne radar data; basal velocity is estimated as $90 \%$ of MEaSUREs surface velocity data (Rignot et al., 2017); basal conductivity is assumed constant following other applications of GlaDS in Antarctica (Dow et al., 2016, 2018). The water input rate is set as constant (both spatially and temporally) at $10 \mathrm{~mm} \mathrm{yr}^{-1}$ following subglacial melt rate calculations.

\subsection{Observed basal melt rate}

The observed ice shelf basal melt rates are computed using a mass conservation approach from surface elevation, surface mass balance, ice velocity, and ice shelf thickness (Jenkins, 1991; Gourmelen et al., 2017b), using the relation (Jenkins, 1991; Gourmelen et al., 2017b)

$-\left(1-\frac{\rho_{\text {ice }}}{\rho_{\text {ocean }}}\right) \dot{m}+\mathrm{SMB}=\frac{\partial S}{\partial t}+S \nabla \cdot \boldsymbol{u}$,

where $\rho_{\text {ice }}$ is ice density of $917 \mathrm{~kg} \mathrm{~m}^{-3}, \rho_{\text {ocean }}$ is the ocean density of $1028 \mathrm{~kg} \mathrm{~m}^{-3}, \dot{m}$ is basal melt rate, SMB is surface mass balance, $S$ is surface elevation, and $\boldsymbol{u}$ is ice velocity. SMB is obtained from output of the regional atmospheric climate model RACMO2 (van Wessem et al., 2016). We derive the rates of surface elevation change from a new elevation data set, which is generated by the CryoSat- 2 interferometric-swath radar altimetry from 2010 to 2016. Ice velocity is acquired from radar observation of the European Space Agency Sentinel-1A satellite. A detailed discussion of the methodology can be found in Gourmelen et al. (2017a). The observed melt rate of Getz is shown in Fig. 2b.

\subsection{Nondischarge melt rate}

We modeled the melt rates over Getz that are expected to result from the in situ far-field ocean temperature. We refer to this modeled melt rate as nondischarge melt rate through this paper since it does not consider any potential impact from local subglacial discharge. Melt rates shown in Fig. $2 b$ are dominated by ocean forcing. On the first order, melt rates are visibly related to ice basal depth, and accordingly we note that melt rates are high where the draft of the ice shelf dips below the $\sim 500 \mathrm{~m}$ depth of the thermocline. As our interest is in exploring the possible mechanisms of melt beyond the first-order effects of ocean forcing, Fig. 3 shows melt rate residuals after the first-order influence of ocean temperature on melt has been removed.

Removing the first-order effects of ocean forcing from the basal-melt-rate distribution requires a model of the relationship between ocean temperature and observed melt rates. Several such models have been proposed and have generally assumed a linear to quadratic relationship between ocean temperature and ice shelf melt rates (Holland et al., 2008). However, estimates determined empirically or through numerical models vary widely, likely due to influences such as basal slope (Little et al., 2009) and basal roughness (Gwyther et al., 2015), which may not be the same for all ice shelves. Here, we use data from Getz to develop only the simplest possible relationship between ocean temperature and melt rates; then we investigate where and how melt observations deviate from the simple first-order model.

To relate the observed melt rates to ocean forcing, we obtain temperature profiles from 25 CTD casts taken within $6 \mathrm{~km}$ of Getz. We converted in situ temperatures to pressureand salinity-dependent temperatures above freezing using the Gibbs-SeaWater Oceanographic Toolbox (McDougall and Barker, 2011). The 25 profiles of $T-T_{\text {freeze }}$ are shown in Fig. 2c. The mean profile of $T-T_{\text {freeze }}$ was then used to interpolate the local temperature above freezing corresponding to the depths of the basal ice in each grid cell of Getz. Ice basal depths were calculated assuming hydrostatic equilibrium for ice of $917 \mathrm{~kg} \mathrm{~m}^{-3}$ density in seawater of $1028 \mathrm{~kg} \mathrm{~m}^{-3}$ density, using REMA surface elevations (Howat et al., 2019) that we converted to the GL04C geoid (Förste et al., 2008; Greene et al., 2017) and from which we removed modeled firn air content (Ligtenberg et al., 2011). The resulting estimated basal temperature distribution is shown in Fig. S6.

\section{Results}

\subsection{The new Getz bathymetry}

The new map of airborne-gravity-derived bathymetry is shown in Fig. 2a. The inversion reveals deep troughs are continuous from the inner continental shelf to beneath the ice shelf. In western Getz we identify a $1300 \mathrm{~m}$ deep trough between Siple Island and Dean Island, which we refer to as Siple-Dean Trough (SDT). In eastern Getz we find a $1200 \mathrm{~m}$ deep trough between Duncan Peninsula and Wright Island, which we refer to as Duncan-Wright Trough (DWT). Published ship track bathymetry (Nitsche et al., 2007) shows that the Dotson-Getz Trough on the inner continental shelf extends to the ice front, and our results suggest that DWT is the continuation of the Dotson-Getz Trough, providing a pathway for CDW to enter into the ice shelf cavity without obstruction. Similarly, SDT is the continuation of the western Getz trough in which unmodified CDW has been reported (Assmann et al., 2019). We note, however, that despite the similar depths and close proximity of DWT to SDT, the two troughs are not connected but are separated by a bathymetric sill that rises to a depth of approximately $500 \pm 240 \mathrm{~m}$ between Siple and Carney islands (Fig. 2a; see methods for uncertainty estimation of the gravity inversion). The free-air gravity field also reflects the general shape of the bathymetric features. Along the profile XYZ (Fig. 2c), the bathymetric 
(a)

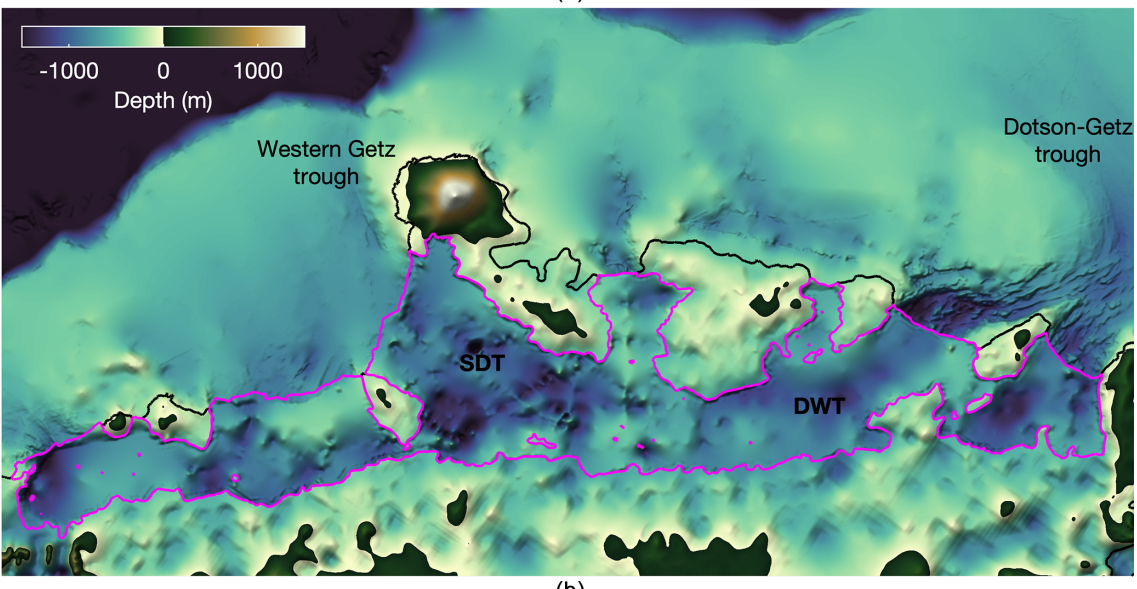

(b)
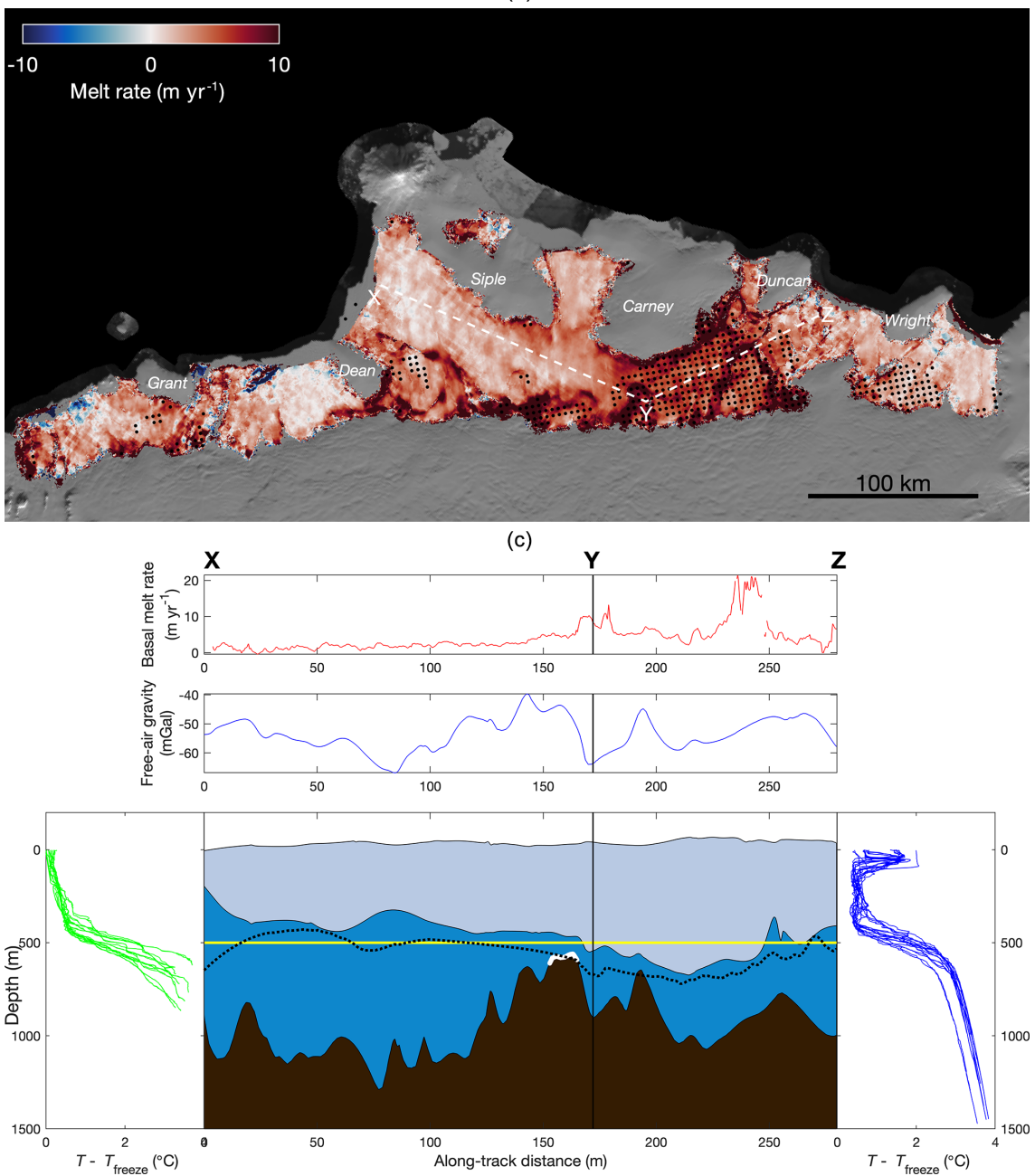

Figure 2. The shape of the seafloor, basal melt rates, and along-profile view of the study area. (a) The bathymetry of the Getz Ice Shelf. The profile XYZ crosses the trough between Dean Island and Siple Island, the bathymetric sill, and the trough between Duncan and Wright Islands. The purple is the ice shelf outline (Mouginot et al., 2017). The bathymetry of the continental shelf is from IBCSO (Arndt et al., 2013). (b) The observed basal melt rate. Black stippling indicates ice bottom elevations that are below the $500 \mathrm{~m}$ depth of the thermocline. The background is the MODIS-derived Mosaic of Antarctica (MOA; Scambos et al., 2007). (c) Upper panel shows the basal melt rate along profile XYZ. The lower panel shows the elevations of ice and bedrock along profile XYZ, with the depth-temperature profiles from western and eastern Getz. Ocean is blue; ice is light blue, and the bedrock is brown. The white indicates the location of the bathymetric sill. The dashed black line is the bathymetry from Bedmap2 (Fretwell et al., 2013). The horizontal yellow line indicates the mean thermocline depth. The thermal forcing $T-T_{\text {freeze }}$ is calculated from CTD casts (Locarnini et al., 2013). 
sill has higher gravity anomaly values. The trough area has low gravity anomaly values.

\subsection{The melt rates of Getz}

\subsubsection{Melt rate from observation}

Figure $2 \mathrm{~b}$ shows our observation of mean basal melt rates from 2010 to 2016. We discover that melt is concentrated along the grounding line especially where it intersects deep troughs. The area-averaged melt under Getz is $4.15 \mathrm{~m} \mathrm{yr}^{-1}$, equating to $141.17 \mathrm{Gt} \mathrm{yr}^{-1}$ of freshwater flux into the Southern Ocean. We find a continuous channelized melt pattern (shown as the dark red in Fig. 2b), from the grounding zone to the eastern Getz calving front. The profile XYZ shown in Fig. 2c is sampled along SDT, the sill, and DWT. The top of the sill sits slightly below the $500 \mathrm{~m}$ thermocline depth and may therefore allow for exchange of warm deep waters between eastern and western Getz. Figure $2 \mathrm{~b}$ shows that the $500 \mathrm{~m}$ ice bottom elevation, represented by the stippled pattern, marks a boundary between low and high melt rates, likely resulting from the warm waters that reside below that depth.

\subsubsection{Melt rate with no subglacial discharge}

To understand how subglacial discharge might affect the melt rate of Getz, we compared the spatial distribution of basal-melt observations to the patterns of melt that are expected to result from a simple depth-dependent model of melt rates (Holland et al., 2008). The simple model assigns melt rates based on the ice shelf draft and a corresponding depthdependent water temperature (see Fig. S6), taken as the mean profile of several nearby oceanographic temperature measurements (Locarnini et al., 2013) (see Sect 2.5, "Nondischarge melt rate"). We refer to this modeled melt distribution as the nondischarge case because it assumes melt is driven only by the in situ far-field ocean temperature and does not consider any potential role of local subglacial discharge. Figure 3 shows the difference between the nondischarge case melt rate and the observed melt rate. The areas where the observed melt rate exceeds the nondischarge melt rate (red area in Fig. 3) correspond to locations of subglacial discharge predicted by GlaDS.

\subsection{The subglacial discharge locations vs. the melt rate difference}

GlaDS predicts subglacial discharge from several major subglacial channels that line up closely with the high melt regions at the ice shelf grounding line. Channel A near Grant Island has the largest channelized relative discharge rate of about $5.3 \mathrm{~m}^{3} \mathrm{~s}^{-1}$, while the channel outlets near the grounding line between Carney Island and Duncan Peninsula have relative discharge rates ranging from 1.76 to $2.4 \mathrm{~m}^{3} \mathrm{~s}^{-1}$. Channel $\mathrm{B}$ near the east of the bathymetric sill has a rela- tive discharge rate of $1.76 \mathrm{~m}^{3} \mathrm{~s}^{-1}$. These channel outlets and relative discharges match up with ice shelf melt rates that are more than $10 \mathrm{~m} \mathrm{yr}^{-1}$. Our work confirms previous findings (Alley et al., 2016; Le Brocq et al., 2013) showing subglacial discharge outlet locations line up well with ice shelf basal channels visible in the MODIS-based Mosaic of Antarctica (MOA) image (Scambos et al., 2007) (see Fig. S7).

\section{Discussion}

\subsection{The continuity of the troughs}

The deep troughs we find extend from the inner continental shelf to Getz and are deep enough to allow for the CDW observed along the ice shelf calving front to enter the ice shelf cavity (Fig. 2c). The continuity of the troughs between the Getz cavity and the continental shelf suggests that the glaciers feeding Getz may have flowed down the deep troughs and onto the continental shelf during the past ice age (Larter et al., 2009; Nitsche et al., 2007). The major troughs we report are not present in the publicly available Bedmap2 (Fretwell et al., 2013) or IBCSO (International Bathymetric Chart of the Southern Ocean) resources (Arndt et al., 2013), and the bathymetric sill we observe is not represented in RTOPO2 (Schaffer and Timmermann, 2016). One exception is the deep trough that is identified east of Wright Island, where the depth of the trough is $200 \mathrm{~m}$ shallower than the trough of the inner continental shelf near the ice shelf front. This new bathymetry will provide important boundary conditions for numerical ocean modeling efforts designed to improve our understanding of ocean heat delivery to coastal ice shelves.

\subsection{Impact of the ice draft on the melt rate}

Previous oceanographic surveys have shown that the Getz melt rate is sensitive to ocean temperature, thermocline depth, circulation strength, bathymetry, and ice thickness (Jacobs et al., 2013). In our study, the factors that may affect the melt rate over the trough area are bathymetry, ice bottom elevation, incursion of warm water, subglacial discharge drained across the grounding line, and the continuity of the troughs from the grounding line to the ice shelf edge (Fig. 2a and b). Differences in melt regimes are apparent between the two troughs we report. Most notably, ice in the DWT experiences a much higher melt rate than ice in the SDT, likely because the deep draft of the eastern Getz places it in warm $\mathrm{CDW}$, whereas the shallow base of the ice to the west sits in relatively cooler water. In eastern Getz, the high-basal-melt region over DWT corresponds to thick ice, where the base sits in the water below the $500 \mathrm{~m}$ thermocline depth (stippled region in Fig. 2b). In addition, the deep trough that is identified east of Wright Island does not correspond to a high melt rate. There is no pathway for CDW intrusion to the ice shelf cavity over that deep trough since the trough is not contin- 


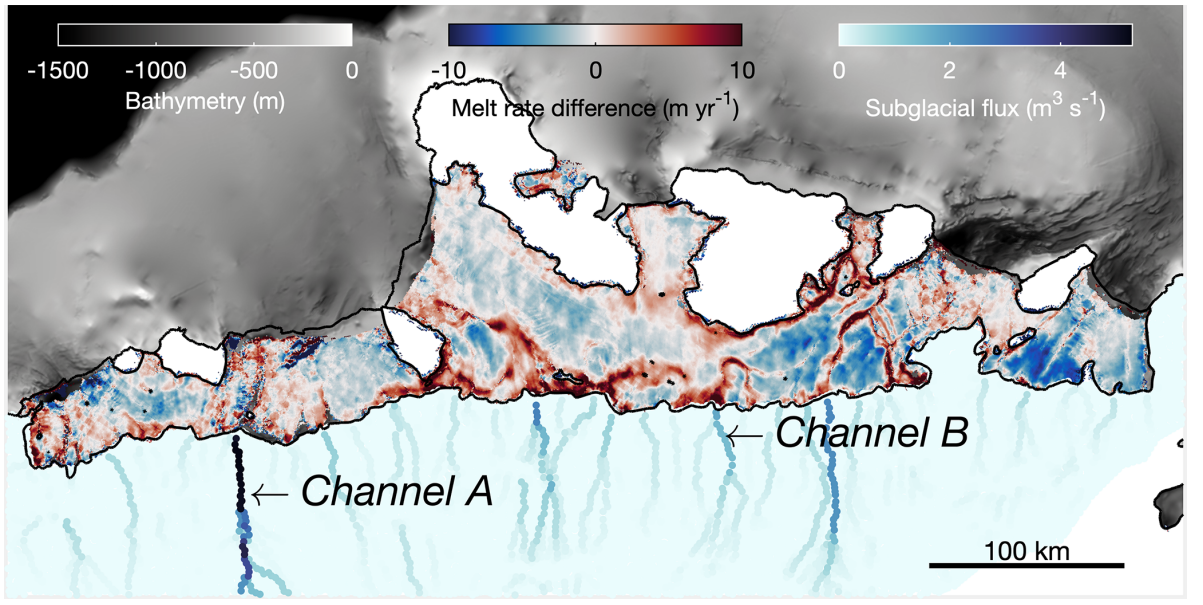

Figure 3. The melt rate difference between observed melt rate and melt rate with no discharge. Red indicates regions where observed melt rates are higher than can be explained by temperature- and depth-dependent forcing alone. The blue fluxes indicate subglacial meltwater. The gray background is the bathymetry from IBCSO (Arndt et al., 2013).

uous from the inner continental shelf to the ice shelf cavity. Therefore, the deep trough that lies east of Wright Island is not associated with major basal melting although the corresponding ice draft is deep (Fig. 2b).

The existence of a trough does not necessarily indicate that the melt rate will be high over it. XY is overlain by a deep trough and allows the incursion of CDW with a high melt rate at the grounding line. However, the ice draft is shallower than the thermocline depth, so we do not observe a high melt rate all along the trough overlaid by XY. Similarly, the melt rate is high over DWT since the ice draft is deeper than the thermocline depth. In addition, subglacial hydrological modeling (Fig. 3) suggests that the subglacial meltwater from the upstream direction may drain through Channel $\mathrm{B}$ and enhance the melt rate near $\mathrm{Y}$. Therefore, although $\mathrm{Y}$ has a relatively shallow bathymetry, we observe a melt rate peak around $\mathrm{Y}$.

\subsection{Impact of the subglacial discharge on the melt rate}

The map of basal melt rate shows several areas of localized high values along channel-like structures connected to the grounding lines. Analysis of subglacial discharge shows a striking connection between predicted channel outlets and high basal melt rates, suggesting that subglacial discharge plays a significant role in regulating the basal melt rate in Getz. Several of the channel outlet locations predicted by GlaDS correspond to ice shelf melt rates that are more than $10 \mathrm{~m} \mathrm{yr}^{-1}$ higher than can be explained by thermal ocean forcing alone (Fig. 3).

Subglacial discharge has been shown to increase basal melt by initiating convective cells carrying heat from warm ocean water below the thermocline to the underside of ice shelves and calving fronts (Jenkins, 2011; Slater et al., 2015). This correspondence is because the subglacial meltwater from the upstream direction drains across the grounding line and induces large but localized sub-ice-shelf melt rates beneath the ice shelf (Le Brocq et al., 2013). One notable exception is Channel A, which pumps more subglacial discharge into the cavity than any other source, yet ice shelf melt rates here are not anomalously high. This is likely due to the presence of a bathymetric high (Fig. 2a) that prevents CDW from entering the Getz cavity to the west of Dean Island. As a result, buoyant subglacial discharge from Channel A does not entrain warm water into its plume or cause elevated channelized melt rates west of Dean Island.

\section{Conclusions}

Our new bathymetry of the Getz Ice Shelf reveals troughs that are continuous from the inner continental shelf to the ice sheet grounding line, which provide natural pathways for CDW to enter into the ice cavity and drive rapid basal melt. We show discharge of subglacial fresh water plays a significant role in regulating the basal melt rate of Getz. Our results confirm the importance of bathymetry and subglacial discharge for understanding ocean forcing on basal mass loss of Antarctic ice shelves. Our study demonstrates the practical use of high-resolution shipborne helicopter gravity to fill critical gaps in seafloor bathymetry in Antarctica, especially over the deep troughs under the ice shelf cavity that generally go undetected in more regional aerogeophysical surveys. These new data will be critical for guiding new airborne- and ground-based surveys, interpreting recent and past ice shelf changes and informing ocean circulation modeling of future impacts for this sector of West Antarctica. The controls from bathymetry and subglacial discharge on the ice shelf basal melting we have found here are likely widespread around Antarctica. Therefore, a similar study over other massive ice shelves similar to Getz should be undertaken in the future. 
Data availability. The IceBridge gravity and radar data were obtained from https://nsidc.org/icebridge/portal/ (last acces: 15 July 2019, Cochran and Bell, 2010b). The CTD casts were obtained from https://www.nodc.noaa.gov/OC5/woa13/ (last access: 15 July 2019, Locarnini, 2013). The CryoSat-2 satellite altimetry data are available at https://earth.esa.int/web/guest/data-access (last access: 15 July 2019, European Space Agency, 2019). The ice velocity data were obtained from https://nsidc.org/data/nsidc-0484/ (last access: 15 July 2019, Rignot et al., 2017). The helicopter gravity data and derived data products in this paper are posted at https://doi.org/10.5281/zenodo.3695943 (Wei et al., 2020).

Supplement. The supplement related to this article is available online at: https://doi.org/10.5194/tc-14-1399-2020-supplement.

Author contributions. WW performed the gravity inversion and wrote the manuscript; JSG assisted with mapping and gravity inversion processing; NG performed the observed-melt-rate calculation; CFD conducted the hydrological model study; CAG estimated nondischarge case melt rate and assisted with the Antarctic Mapping Tool; DDB and DAY helped with the geophysical interpretations; KA contributed the oceanographic inputs; TGR, SHL, TWK, and WSL contributed to the helicopter gravity data collection. All authors contributed comments on the interpretation of results and preparation of the final paper.

Competing interests. The authors declare that they have no competing financial interests.

Acknowledgements. This work was supported by the National Science Foundation (NSF) project (grant no. PLR-1543452), G. Unger Vetlesen Foundation, and UTIG Gale White Fellowship. The nondischarge case melt rate research was carried out at the Jet Propulsion Laboratory, California Institute of Technology, under a contract with the National Aeronautics and Space Administration. Work on the observed melt rate was funded by the European Space Agency's Support to Science Element program through the CryoTop Evolution project 4000116874/16/I-NB (Noel Gourmelen). We thank KOPRI and Helicopters New Zealand for collecting the helicopter gravity data across the Amundsen Sea sector. The helicopter gravity survey is supported by the South Korean Ministry of Oceans and Fisheries (KIMST20190361; PM19020) and KOPRI PE18060. We acknowledge and thank Seequent Limited for supporting this project through access to the Geosoft Software suite which was used to compute the bathymetry inversion. This is UTIG contribution 3643 .

Financial support. This research has been supported by the National Science Foundation (grant no. PLR-1543452) and the G. Unger Vetlesen Foundation.
Review statement. This paper was edited by Kenichi Matsuoka and reviewed by Tom Jordan and one anonymous referee.

\section{References}

Alley, K. E., Scambos, T. A., Siegfried, M. R., and Fricker, H. A.: Impacts of warm water on Antarctic ice shelf stability through basal channel formation, Nat. Geosci., 9, 290-293, https://doi.org/10.1038/ngeo2675, 2016.

Arndt, J., Schenke, H., Jakobsson, M., Nitsche, F. O., Buys, G., Goleby, B., Rebesco, M., Bohoyo, F., Hong, J., and Black, J.: The International Bathymetric Chart of the Southern Ocean (IBCSO) Version 1.0 - A new bathymetric compilation covering circum Antarctic waters, Geophys. Res. Lett., 40, 3111-3117, https://doi.org/10.1002/grl.50413, 2013.

Assmann, K., Darelius, E., Wåhlin, A., Kim, T., and Lee, S.: Warm Circumpolar Deep Water at the Western Getz Ice Shelf Front, Antarctica, Geophys. Res. Lett., 46, 870-878, https://doi.org/10.1029/2018gl081354, 2019.

Briggs, I. C.: Machine contouring using minimum curvature, Geophysics, 39, 39-48, 1974.

Cochran, J. and Bell, R.: IceBridge Sander AIRGrav L1B Geolocated Free Air Gravity Anomalies, Version 1 [updated 2018], Boulder, Colorado USA, NASA National Snow and Ice Data Center Distributed Active Archive Center, https://doi.org/10.5067/R1RQ6NRIJV89, 2010a.

Cochran, J. and Bell, R.: IceBridge Sander AIRGrav L1B, Geolocated Free Air Gravity Anomalies, Version 1,available at: https: //nsidc.org/icebridge/portal/ (last access date: 15 July 2019), 2010 b.

Cochran, J. R., Jacobs, S. S., Tinto, K. J., and Bell, R. E.: Bathymetric and oceanic controls on Abbot Ice Shelf thickness and stability, The Cryosphere, 8, 877-889, https://doi.org/10.5194/tc8-877-2014, 2014.

Cochran, J. R. and Bell, R. E.: Inversion of IceBridge gravity data for continental shelf bathymetry beneath the Larsen Ice Shelf, Antarctica, J. Glaciol., 58, 540-552, https://doi.org/10.3189/2012JoG11J033, 2012.

Dow, C. F., Werder, M. A., Nowicki, S., and Walker, R. T.: Modeling Antarctic subglacial lake filling and drainage cycles, The Cryosphere, 10, 1381-1393, https://doi.org/10.5194/tc-10-13812016, 2016.

Dow, C. F., Werder, M. A., Babonis, G., Nowicki, S., Walker, R. T., Csathó, B., and Morlighem, M.: Dynamics of active subglacial lakes in Recovery Ice Stream, J. Geophys. Res.-Earth, 123, 837850, 2018.

Dow, C. S., McCormack, F. S., Young, D. A., Greenbaum, J. S., Roberts, J. L., and Blankenship, D. D.: Totten Glacier subglacial hydrology determined from geophysics and modeling, Earth Planet. Sc. Lett., 531, 115961, https://doi.org/10.1016/j.epsl.2019.115961, 2020.

European Space Agency: L1b SARin Precise Orbit, available at: https://earth.esa.int/web/guest/data-access, last access: 15 July 2019.

Förste, C., Schmidt, R., Stubenvoll, R., Flechtner, F., Meyer, U., König, R., Neumayer, H., Biancale, R., Lemoine, J. M., Bruinsma, S. and Loyer, S.: The GeoForschungsZentrum Potsdam/Groupe de Recherche de Geodesie Spatiale satellite- 
only and combined gravity field models: EIGEN-GL04S1 and EIGEN-GL04C, J. Geodesy, 82, 331-346, 2008.

Fretwell, P., Pritchard, H. D., Vaughan, D. G., Bamber, J. L., Barrand, N. E., Bell, R., Bianchi, C., Bingham, R. G., Blankenship, D. D., Casassa, G., Catania, G., Callens, D., Conway, H., Cook, A. J., Corr, H. F. J., Damaske, D., Damm, V., Ferraccioli, F., Forsberg, R., Fujita, S., Gim, Y., Gogineni, P., Griggs, J. A., Hindmarsh, R. C. A., Holmlund, P., Holt, J. W., Jacobel, R. W., Jenkins, A., Jokat, W., Jordan, T., King, E. C., Kohler, J., Krabill, W., Riger-Kusk, M., Langley, K. A., Leitchenkov, G., Leuschen, C., Luyendyk, B. P., Matsuoka, K., Mouginot, J., Nitsche, F. O., Nogi, Y., Nost, O. A., Popov, S. V., Rignot, E., Rippin, D. M., Rivera, A., Roberts, J., Ross, N., Siegert, M. J., Smith, A. M., Steinhage, D., Studinger, M., Sun, B., Tinto, B. K., Welch, B. C., Wilson, D., Young, D. A., Xiangbin, C., and Zirizzotti, A.: Bedmap2: improved ice bed, surface and thickness datasets for Antarctica, The Cryosphere, 7, 375-393, https://doi.org/10.5194/tc-7-375-2013, 2013.

Gohl, K., Denk, A., Eagles, G., and Wobbe, F.: Deciphering tectonic phases of the Amundsen Sea Embayment shelf, West Antarctica, from a magnetic anomaly grid, Tectonophysics, 585, 113-123, 2013.

Gourmelen, N., Escorihuela, M., Shepherd, A., Foresta, L., Muir, A., Garcia-Mondejar, A., Roca, M., Baker, S., and Drinkwater, M.: CryoSat-2 swath interferometric altimetry for mapping ice elevation and elevation change, Adv. Space Res., 62, 1226-1242, 2017a.

Gourmelen, N., Goldberg, D., Snow, K., Henley, S., Bingham, R., Kimura, S., Hogg, A., Shepherd, A., Mouginot, J., Lenaerts, J., Ligtenberg, S., and Berg, W.: Channelized melting drives thinning under a rapidly melting Antarctic ice shelf, Geophys. Res. Lett., 44, 9796-9804, https://doi.org/10.1002/2017GL074929, $2017 b$.

Greenbaum, J., Blankenship, D., Young, D., Richter, T., Roberts, J., Aitken, A., Legresy, B., Schroeder, D., Warner, R., Ommen, T., and Siegert, M.: Ocean access to a cavity beneath Totten Glacier in East Antarctica, Nat. Geosci., 8, 294-298, https://doi.org/10.1038/ngeo2388, 2015.

Greene, C. A., Gwyther, D. E., and Blankenship, D. D.: Antarctic Mapping Tools for MATLAB, Comput. Geosci., 104, 151-157, https://doi.org/10.1016/j.cageo.2016.08.003, 2017.

Gwyther, D. E., Galton-Fenzi, B. K., Dinniman, M. S., Roberts, J. L., and Hunter, J. R.: The effect of basal friction on melting and freezing in ice shelf-ocean models, Ocean Model., 95, 3852, 2015.

Holland, P. R., Jenkins, A., and Holland, D. M.: The response of ice shelf basal melting to variations in ocean temperature, J. Climate, 21, 2558-2572, 2008.

Howat, I. M., Porter, C., Smith, B. E., Noh, M.-J., and Morin, P.: The Reference Elevation Model of Antarctica, The Cryosphere, 13, 665-674, https://doi.org/10.5194/tc-13-665-2019, 2019.

Jacobs, S., Giulivi, C., Dutrieux, P., Rignot, E., Nitsche, F., and Mouginot, J.: Getz Ice Shelf melting response to changes in ocean forcing, J. Geophys. Res.-Oceans, 118, 4152-4168, https://doi.org/10.1002/jgrc.20298, 2013.

Jenkins, A.: A one-dimensional model of ice shelf-ocean interaction, J. Geophys. Res.-Oceans, 96, 20671-20677, 1991.
Jenkins, A.: Convection-driven melting near the grounding lines of ice shelves and tidewater glaciers, J. Phys. Oceanogr., 41, 22792294, 2011.

Jourdain, N. C., Mathiot, P., Merino, N., Durand, G., Le Sommer, J., Spence, P., Dutrieux, P., and Madec, G.: Ocean circulation and sea-ice thinning induced by melting ice shelves in the Amundsen Sea, J. Geophys. Res.-Oceans, 122, 2550-2573, 2017.

Larter, R. D., Graham, A. G., Gohl, K., Kuhn, G., Hillenbrand, C.D., Smith, J. A., Deen, T. J., Livermore, R. A., and Schenke, H.W.: Subglacial bedforms reveal complex basal regime in a zone of paleo-ice stream convergence, Amundsen Sea Embayment, West Antarctica, Geology, 37, 411-414, 2009.

Le Brocq, A. M., Ross, N., Griggs, J. A., Bingham, R. G., Corr, H. F., Ferraccioli, F., Jenkins, A., Jordan, T. A., Payne, A. J., Rippin, D. M., and Siegert, M. J.: Evidence from ice shelves for channelized meltwater flow beneath the Antarctic Ice Sheet, Nat. Geosci., 6, 945-948, https://doi.org/10.1038/ngeo1977, 2013.

Ligtenberg, S. R. M., Helsen, M. M., and van den Broeke, M. R.: An improved semi-empirical model for the densification of Antarctic firn, The Cryosphere, 5, 809-819, https://doi.org/10.5194/tc-5809-2011, 2011.

Little, C. M., Gnanadesikan, A., and Oppenheimer, M.: How ice shelf morphology controls basal melting, J. Geophys., 114, C12007, https://doi.org/10.1029/2008jc005197, 2009.

Locarnini, R. A.: World Ocean Atlas 2013, available at: https: //www.nodc.noaa.gov/OC5/woa13/ (last access: 15 July 2019), 2013.

Locarnini, R., Mishonov, A., Antonov, J., Boyer, T., Garcia, H., Baranova, O., Zweng, M., Paver, C., Reagan, J., and Johnson, D.: World Ocean Atlas 2013, vol. 1, Temperature, edited by: Levitus, S., NOAA Atlas NESDIS, 73, 40 pp., 2013.

Marsh, O. J., Fricker, H. A., Siegfried, M. R., Christianson, K., Nicholls, K. W., Corr, H. F., and Catania, G.: High basal melting forming a channel at the grounding line of Ross Ice Shelf, Antarctica, Geophys. Res. Lett., 43, 250-255, https://doi.org/10.1002/2015g1066612, 2016.

McDougall, T. and Barker, P.: Getting started with TEOS-10 and the Gibbs Seawater (GSW) Oceanographic Toolbox, SCOR/IAPSO WG127, 2011.

Millan, R., Rignot, E., Bernier, V., Morlighem, M., and Dutrieux, P.: Bathymetry of the Amundsen Sea Embayment sector of West Antarctica from Operation IceBridge gravity and other data, Geophys. Res. Lett., 44, 1360-1368, https://doi.org/10.1002/2016GL072071, 2017.

Mouginot, B., Scheuchl, J., and Rignot, E.: MEaSUREs Antarctic boundaries for IPY 2007-2009 from satellite radar, version 2, Boulder, CO: NASA National Snow and Ice Data Center Distributed Active Archive Center, https://doi.org/10.5067/AXE4121732AD, 2017.

Mukasa, S. B. and Dalziel, I. W.: Marie Byrd Land, West Antarctica: Evolution of Gondwana's Pacific margin constrained by zircon $\mathrm{U}-\mathrm{Pb}$ geochronology and feldspar common-Pb isotopic compositions, Geol. Soc. Am. B., 112, 611-627, https://doi.org/10.1130/00167606(2000)112<611:MBLWAE>2.0.CO;2, 2000.

Muto, A., Peters, L. E., Gohl, K., Sasgen, I., Alley, R. B., Anandakrishnan, S., and Riverman, K. L.: Subglacial bathymetry and sediment distribution beneath Pine Island Glacier ice shelf mod- 
eled using aerogravity and in situ geophysical data: New results, Earth Planet. Sc. Lett., 433, 63-75, 2016.

Nakayama, Y., Timmermann, R., Rodehacke, C. B., Schröder, M., and Hellmer, H. H.: Modeling the spreading of glacial meltwater from the Amundsen and Bellingshausen Seas, Geophys. Res. Lett., 41, 7942-7949, 2014.

Nitsche, F., Jacobs, S., Larter, R., and Gohl, K.: Bathymetry of the Amundsen Sea continental shelf: Implications for geology, oceanography, and glaciology, Geochem. Geophys. Geosyst., 8, Q10009, https://doi.org/10.1029/2007GC001694, 2007.

Paolo, F. S., Fricker, H. A., and Padman, L.: Volume loss from Antarctic ice shelves is accelerating, Science, 348, 327-331, https://doi.org/10.1126/science.aaa0940, 2015.

Raiswell, R., Tranter, M., Benning, L. G., Siegert, M., De'ath, R., Huybrechts, P., and Payne, T.: Contributions from glacially derived sediment to the global iron (oxyhydr) oxide cycle: implications for iron delivery to the oceans, Geochim. Cosmochim. Ac., 70, 2765-2780, https://doi.org/10.1016/j.gca.2005.12.027, 2006.

Rignot, E., Jacobs, S., Mouginot, J., and Scheuchl, B.: Iceshelf melting around Antarctica, Science, 341, 266-270, https://doi.org/10.1126/science.1235798, 2013.

Rignot, E., Mouginot, J., and Scheuchl, B.: MEaSUREs InSARbased Antarctica ice velocity map, Version 2. Boulder, Colorado USA. NASA National Snow and Ice Data Center Distributed Active Archive Center, available at: https://nsidc.org/ data/nsidc-0484/ (last access: 15 July 2019), 2017.

Scambos, T., Haran, T., Fahnestock, M., Painter, T., and Bohlander, J.: MODIS-based Mosaic of Antarctica (MOA) data sets: Continent-wide surface morphology and snow grain size, Remote Sens. Environ., 111, 242-257, 2007.

Schaffer, J. and Timmermann, R.: Greenland and Antarctic ice sheet topography, cavity geometry, and global bathymetry (RTopo-2), links to NetCDF files, https://doi.org/10.1594/PANGAEA.856844, 2016.
Silvano, A., Rintoul, S. R., Peña-Molino, B., Hobbs, W. R., van Wijk, E., Aoki, S., Tamura, T., and Williams, G. D.: Freshening by glacial meltwater enhances melting of ice shelves and reduces formation of Antarctic Bottom Water, Sci. Adv., 4, eaap9467, https://doi.org/10.1126/sciadv.aap9467, 2018.

Slater, D., Nienow, P., Cowton, T., Goldberg, D., and Sole, A.: Effect of near terminus subglacial hydrology on tidewater glacier submarine melt rates, Geophys. Res. Lett., 42, 2861-2868, https://doi.org/10.1002/2014GL062494, 2015.

Talwani, M., Worzel, L. J., and Landisman, M.: Rapid gravity computations for two-dimensional bodies with application to the Mendocino submarine fracture zone, J. Geophys. Res., 64, 4959, https://doi.org/10.1029/jz064i001p00049, 1959.

Tinto, K. and Bell, R.: Progressive unpinning of Thwaites Glacier from newly identified offshore ridge: Constraints from aerogravity, Geophys. Res. Lett., 38, L20503, https://doi.org/10.1029/2011GL049026, 2011.

van Wessem, J. M., Ligtenberg, S. R. M., Reijmer, C. H., van de Berg, W. J., van den Broeke, M. R., Barrand, N. E., Thomas, E. R., Turner, J., Wuite, J., Scambos, T. A., and van Meijgaard, E.: The modelled surface mass balance of the Antarctic Peninsula at $5.5 \mathrm{~km}$ horizontal resolution, The Cryosphere, 10, 271-285, https://doi.org/10.5194/tc-10-271-2016, 2016.

Werder, M. A., Hewitt, I. J., Schoof, C. G., and Flowers, G. E.: Modeling channelized and distributed subglacial drainage in two dimensions, J. Geophys. Res.-Earth, 118, 2140-2158, https://doi.org/10.1002/jgrf.20146, 2013.

Wei, W., Blankenship, D. D., Greenbaum J. S., Gourmelen, N., Dow, C. F., Richter, T. G., Greene, C. A., Young, D. A., Lee, S., Lee, W. S., and Assmann, K. M.: Getz Ice Shelf melt enhanced by freshwater discharge from beneath the West Antarctic Ice Sheet, Zenodo, https://doi.org/10.5281/zenodo.3695943, 2020. 